\title{
Human Resource Development As a Tool For Empowering Grassroot Communities For Improved Community Development Programmes In Osun State, Nigeria
}

\author{
Oyebamiji, M. A. Ph.d \\ Department of Adult \& Non-Formal Education, Faculty of Education \\ University of Port Harcourt, Port Harcourt, Nigeria \\ E-mail: morufu.oyebamiji@uniport.edu.ng
}

Adekola, G. Ph.d

Department of Adult \& Non-Formal Education, Faculty of Education

University of Port Harcourt, Port Harcourt, Nigeria

Accepted: December 4, 2011 Published: January 9, 2012

doi:10.5296/ijhrs.v2i1.1251 URL: http://dx.doi.org/10.5296/ijhrs.v2i1.1251

\begin{abstract}
This paper is on Human Resource Development as a tool for empowering grassroots communities for improved community development in Osun State, Nigeria. It evaluates the various human resource development programmes organized by the state for Community Development Committees (CDC) and their impact on community development programmes of Osun State. A descriptive survey research method was adopted for the study. A total of three hundred and fifty (350) Community Development Committee members were randomly selected from six administrative zones of Osun State using stratified sampling technique. Human Resource Development Empowering Programme for Community Development Committee Members Questionnaire (HRDEPCDCMQ) was used, and was complemented with Focus Group Discussion (FGD) technique to collect information from the respondents. Four research questions were generated. The data collected was analyzed using multiple regression analysis, Pearson Product Moment Correlation and t-test statistical methods. It was discovered that Human Resource Development promotes in the CDC members the needed skills for problem identification, planning, monitoring, implementation and evaluation of community development programmes/projects. That HRD provides the
\end{abstract}


satisfaction and motivation for the CDC to handle community development projects as their own project for improved community development programmes in their communities. It is therefore recommended that the government at all levels should encourage continuous development of the power of work in both the CDC and the change agents at the locality levels for improved community development programmes delivery in Osun State and Nigeria at large.

KEY WORDS: Human Resource Development, Empowerment, Community Development, Grassroot.

\section{Introduction}

Community development is focused on two broad objectives, namely to achieve physical targets such as material improvement of the community e.g. schools, wells, hospitals, roads etc. The second objective of community development is on activities that will build the community through improving the individuals and making them the builders of their community and architect of their own well-being. Community development therefore aimed at developing the people through improvement in the conditions of their local communities.

Man activates development process and manpower is the resources. Oshionebo (2000) asserts that the wide development gap between the industrialized countries and the developing nations of the world is clearly seen from great inequalities in the range and level of knowledge and skills in use. A growing recognition of the fact that investment in human capital not only promotes development in the use of physical capital but also promotes a very high rate of returns.

According to Harbison (1965:75) emphasizing on the importance of investing in human as an asset for development states that:

The wealth of a country is dependent not so much upon its natural resources and material capital; it is determined in a significant degree by the knowledge, skills and motivation of its people.

The capacity of a country to effectively achieve accelerated development is determined by the human factor. The human factor is the amalgam capacity and capability available within an economy and which prior whether socio-economic growth can be achieved. The human factor in any community development programme becomes significant base on the fact that successful community development activities will be determined by the competence, motivation and general effectiveness of its human are the active agent of change, they play a very crucial role in the development of a nation.

The need for the mass mobilization and education of the people so as to achieve meaningful participation in the process of community development i.e. need identification, planning, monitoring/implementation and evaluation can not be understated. The new orientation of community development demands of the acquisition of new skills and work ethics which will heighten the work efficiency of the people. In all, community development demands in this computer age scientific and critical sprit. 
Human resource development will serve as an instrument per-excellence for the sharing of the latest and the most pertinent knowledge, skills and training with the people to match effectively what seems avalanche of technological improvement. Society's changes according to the changing conditions of time, therefore all adults should learn and continue learning so as to equip themselves to meet the challenges of modern development trends and to contribute effectively towards the economic and social development of our communities.

There has been lots of community development projects by both government and non-governmental organizations in Osun State, Nigeria, which suppose to benefit the communities where such projects are located. These projects have not been effective as most of it are abandoned, misused, uncompleted and at times mis-managed. These problems emanated from the fact that the benefiting communities are not involved in the need identification, planning, monitoring, implementing and evaluation of such development projects. The believe of both the government and NOGs is based on the fact that they see the benefiting communities as lacking the necessary knowledge and skills needed for such development projects to be successfully implemented.

In an attempt to reduce the rate of project abandonment, misuse, and been mismanaged, efforts at getting benefiting communities involved in the process of community development was promoted by the state government through the constitution of Community Development Committee (CDC) in all nooks and crannies of the state. for the CDC to function effectively, the state and the local governments came up with the idea of enhancing he capacity for developing the communities through the CDC by organizing training, education and workshops for the revitalization of all members. There is therefore a need to determine how human resource development programmes organized for the CDC in the state by the government enhanced effective community development.

This study therefore will be anchored on the different human resource development programmes of the state for the CDC and how it has promoted in them the skills, knowledge, competence, and motivation for improved community development in Osun State, and Nigeria in general.

Human resource development is an organized learning experiences in a definite time period to increase the possibility of improving job performance growth (Nadler, 1990). Thus, learning can take place in a variety of ways i.e. formal, non-formal or incidental. Gbeja (2002) defined human resource development as all the activities that are geared towards enhancing an individual's disposition to the acquisition of requested knowledge, development of desired skills and adoption of relevant attitude and aptitudes, all of which enable the individual to have the ability that is invaluable for satisfactory performance of a given task which cumulatively lead to the attainment of targets and objects.

This implies that human aspect of capacity building relates to the stock of trained, skilled and productive manpower which can perform key tasks required for an organization to achieve its corporate goals or for a community to achieve its development objectives. Balogun, (2003) was of the view that the development of any community or nation depends to a large extent on the caliber organization and motivation of its human resources. Human resource development encompasses the personal, social, economic, moral, intellectual and spiritual development of the individuals. Effective community change demands for a 
dynamic human resource development.

Improved community development practice demands emphasis on training and retraining of CDC members so as to ensure that each member possesses requisite knowledge, skills, expertise and experience for the performance of community development tasks. Manpower development through formal, non-formal and informal education are crucial for increased performance. The importance of human resource development in community can not be underplayed. As Onyeozu (2007) submits, "if community development activities are to be identified as such, then, it must possess the three key elements of community development which are felt need, self-help and popular participation. In other words, members of the community must be actively involved in all the stages of community development programmes.

The first stage of community development is identification of community felt needs, the stage of planning of community development projects, monitoring, implementation stages as well as evaluation and management of community development projects or programmes as the need arises. The success or failure of community development depends to a large extent on the level of participation by those involved. Community Development Committee plays significant role in the realization of these goals. Therefore, human resource development facilitates community development as it will help to:

(a) develop in all CDC members the requisite knowledge for need identification;

(b) develop the appropriate skills, expertise and attitudes of the CDC through training and re-training. (Oyebamiji \& Adekola 2008).

\section{Statement of the Problem}

Many development projects that suppose to benefit member communities carried out by government, non-governmental organizations and philanthropists in Osun State have not been effective as most of its are abandoned, misused and uncompleted. Lack of involvement of the benefiting communities in project identification as it reflects their needs, planning, implementing and evaluation of the relevance to their needs subsumed form the believe that benefiting communities lack the requisite knowledge for such activities. To reduce the rate of project abandonment, misuse and uncompletion, this paper is anchored on the relevance of human resource development in promoting such skills, knowledge and ability to handle at the community level their own projects sustainable.

\section{Objectives of the Study}

Specifically, the objectives of the study are;

(1) To determine the relationship between human resource development training for the CDC and appropriate need identification, planning and implementation.

(2) To ascertain the combined contributions of HRD to need identification, planning and implementation by the CDC of projects and commitment to its sustainability.

(3) Determine the variation in the level of commitment of CDC male and female members in community development need identification, planning and implementing. 


\section{Research Questions}

The study sought to provide answers to the following questions;

(1) What is the combined influence of HRD empowering programme for CDC need identification, planning and implementation of community development projects?

(2) To what extent would need identification, planning and implementation promotes sustainable community development?

(3) Is there any variation in the level of commitment of CDC male and female in community development need identification, planning and implementation?

\section{Scope of the Study}

The scope of this study covers the six administrative zones of Osun State, namely Ede, Ife, Ikirun, Ilesa, Iwo, and Osogbo. One local government each was randomly selected from the zones.

\section{Methodology}

The descriptive survey method was adopted for the study. This was to enable the researchers deal with variables in the study without manipulating the data collected. The population of the study comprised all CDC members of the six administrative zones of Osun State.

Stratified random sampling technique was used to select a sample of (350) three hundred and fifty CDC members for the study. A structured questionnaire tagged Human Resource Development Empowering Programme for Community Development Committee Members Questionnaire (HRDEPCDMQ) served as the main instrument for data collection. This was complemented with a Focus Group discussion (FGD) technique. The instrument were administered with the assistance of six trained research assistants who visited the administrative zones for a period of five days to administer the instruments on the sample elements of the study.

\section{Method of Data Analysis}

The data collected from the field were analyzed using multiple Regression analysis, Person Product Movement Correlation and t-test statistical methods.

\section{Result}

Research Question 1: What is the combined influence of HRD Empowering Programme on CDC's ability to properly Identify Communities needs, plan and implement Community development projects sustainable? 
Table 1: Summary of Regression Analysis on HRD empowering programme on appropriate need identification, planning and implementation of Community Development Projects by CDC members.

\begin{tabular}{|l|l|l|l|l|l|l|}
\hline & Sum of squares & df & Mean square & F & P & Remark \\
\hline Regression & 1851.650 & 2 & 9.25 .840 & 38.537 & 0.000 & $*$ \\
\hline Residual & 8336.77 & 347 & 24.025 & & & \\
\hline Total & 10188.357 & 349 & & & & \\
\hline
\end{tabular}

$*$ Significant $(\mathrm{p}<0.05)$

Table 1 reveals that Human Resource Development Empowering Programmes for Community Development Committee Assists in appropriate identification of community needs, adequate planning and proper implementation of projects at the community levels. Appropriate need identification; planning based on community resource and implementation makes for success in any community development projects.

Research Question 2: To what extent would need identification, planning and implementation promotes sustainable community development?

Table 2: Summary of correlation matrix of need identification, planning and implementation for sustainable development.

\begin{tabular}{|l|l|l|l|}
\hline & Need identification & $\begin{array}{l}\text { Planning and } \\
\text { implementation }\end{array}$ & $\begin{array}{l}\text { HRD for Sustainable } \\
\text { Development }\end{array}$ \\
\hline Need identification & 1000 & & \\
\hline $\begin{array}{l}\text { Planning } \\
\text { implementation }\end{array}$ & 0.709 & 1.000 & 1.000 \\
\hline $\begin{array}{l}\text { HRD for sustainable } \\
\text { community development }\end{array}$ & 0.413 & 0.368 & \\
\hline
\end{tabular}

These variables are highly inter correlated. There is high positive correlation between need identification, planning and implementation with human resource development empowering programmes for sustainable Community Development projects. 
Research Question 3: Is there any variation in the level of commitment of CDC male and female members in community development need identification, planning and implementation after receiving HRD empowering training.

Table 3: Sumamry of t-test analysis on extent to which HRD empowering programme influence male CDC participants than female CDC participants.

\begin{tabular}{|c|c|c|c|c|c|c|c|}
\hline Variables & $\mathrm{CDC}$ & $\mathrm{N}$ & Mean & $\begin{array}{l}\text { Standard } \\
\text { deviation }\end{array}$ & $\mathrm{t}$ & $\mathrm{p}$ & Remarks \\
\hline \multirow{2}{*}{$\begin{array}{l}\text { Need } \\
\text { identification }\end{array}$} & Male & 207 & 66.387 & 9.538 & \multirow{2}{*}{0.183} & \multirow{2}{*}{0.855} & \multirow{2}{*}{ NS } \\
\hline & Female & 143 & 66.220 & 7.816 & & & \\
\hline \multirow{2}{*}{$\begin{array}{l}\text { Planning \& } \\
\text { implementation }\end{array}$} & Male & 207 & 45.918 & 7.671 & \multirow{2}{*}{1.084} & \multirow{2}{*}{0.279} & \multirow{2}{*}{ NS } \\
\hline & Female & 143 & 45.049 & 6.909 & & & \\
\hline \multirow[b]{2}{*}{$\begin{array}{l}\text { HRD } \\
\text { Empowering } \\
\text { Programme's } \\
\text { enhancement } \\
\text { for CDC's } \\
\text { commitment }\end{array}$} & Male & 207 & 59.232 & 4.705 & \multirow[b]{2}{*}{0.46} & \multirow[b]{2}{*}{0.964} & \multirow[b]{2}{*}{ NS } \\
\hline & Female & 143 & 66.220 & 7.816 & & & \\
\hline
\end{tabular}

$\mathrm{NS}=$ Not significant $(\mathrm{p}>0.05)$

On the table above, each of the variables has no significant difference between male and female CDC. They are equally committed to communities need identification, planning and implementation of projects after undergone HRD training.

\section{Discussion}

The analysis of data on research question one as indicated in table 1 shows that human resource development empowering programmes for community to identify community felt needs, priorities than in the order of urgency and plan with the limited resources available within the community for appropriate implementation to be done. This finding is in line with Balogun (2003) that the development of any community or nation depends to a large extent on the caliber organization and motivation of its human resources. This implies that human aspect of capacity building relates to the stock of trained, skilled and productive manpower which can perform they key tasks required for an organization or community to achieve its corporate goals or development objectives. The finding supports Onyeozu (2007) Oyebamiji and Adekola (2008) that improved community development practice demands emphasis on training and retraining of community development committees so as to ensure that each members possesses requite knowledge, skills, expertise and experience for the performance of community development tasks.

Table two in this study revealed that human resource development empowering programmes for CDC members have positive correlation with the knowledge, skills and capacity to identify community needs, plan towards the prioritized needs so identified and come up with appropriate strategies to implement it, bearing in mind available resources for 
such project by the community. The finding is in line with Gbeja (2002) that human resource development is all the activities that are geared towards enhancing an individual's disposition to the acquisition of requite knowledge, development of desired skills and adoption of relevant attitude and aptitudes, all of which enable the individual to have the ability that is invaluable for satisfactory performance of a given task which cumulatively lead to the attainment of targets and objects.

The three revealed that no significant difference occurred between male and female CDC members that participated in the HRD empowering programmes for improved community development in terms of performance and commitment. The knowledge and skills acquired by both male and female during the HRD empowering process equipped them equally to perform the task of identification of community needs, plan and implement according to the resources available in the community. The finding is in line with Oyebamiji and Adekola (2008) that human resource development facilitates community development because it develop in CDC members the requisite knowledge for need identification, develop the appropriate skills, expertise and attitudes of the CDC through training and re-training.

\section{Conclusion and Recommendations}

Based on the findings of this study, it is concluded that human resource development empowering programmes in Osun State promotes knowledge, skills, attitudes and aptitudes for proper need identification, planning and implementation of community development programmes. The study further concludes that continuous training and retraining of CDC members enhances capability building for sustainable community development programme. Both male and female members of the CDC in the six administrative zones of Osun state became more efficient, effective and committed to peoples needs, plan and implement based on community resource. HRD have promoted in the CDC members new skills and techniques which have made them better.

The study therefore recommends that CDC members should be encouraged to get involved in training and retraining programs for knowledge, skills and aptitude necessary for improved implementation of community development programmes in the state. such programmes should be regularly provided for CDC members in order to improve their skills and competence. It is also recommended that government should provide adequate funds, learning facilities through adult and non-formal education and trained instructors so that HRD programmes will be effective. Finally, learning content should be up-dated so as to meet the needed capacities to be developed among CDC members for improved community development programme implementation. 


\section{References}

Adult Education and Development (2010). Community Learning Centres: Experiences from Asia, Latin America, Africa and Europe. DVV International.

Anyanwu, C. N. (1992). Community Development: The Nigeria Perspective, Ibadan: Gabesther Educational Publishers.

Balogun, J. M. (2003) “Nigeria's Public Service Reform Process: Human resource Issues”. Article Retrieve $10^{\text {th }} \quad$ October from http://unpanl.un.org/intradox/groups/public/document/CAFRD/UNPAN01072.pdf

Gbeja, O.O. (2002). Professional Trainning and Capacity Building in Nigewria matters arising. A paper presented at a workshop on the Role of Prefessionals in Nation Building: The Issue of Ethics and Consequence of failure. African Leadership Forum, Otta. $11^{\text {th }}$ to $14^{\text {th }}$ September.

Harbison, F. (1965) Human Resources as the wealth of New Nations, New York: McGraw Hill Publishers.

Nadler, L. \& Nadler, Z. (1990). The Handbook of Human Resource Development $\left(2^{\text {nd }}\right.$ Edition), New York: John Wiley \& son.

Onyeozu, A. M. (2007). Understanding community development, Port Harcourt David Stones Publishers.

Oshionebo, B. O. (2000). Capacity Building in a Democratic Era in Bello-Imam, I. B. \& Obadan, M. I. (eds) Democratic Governance and Development Management in Nigeria's fourth Republic 1999-2003: Centre for Local Government and Rural Development Studies, Ibadan Jodad Publisehrs.

Oyebamiji, M. A. (2005). Non-formal Education Programme and Income Generation Activities among women at the Grassroots in Oyo and Osun state, Nigeria: A comparative Study, International Journal of Labour and Trade Unionism 1(1): 75-83.

Oyebamiji, M. A. \& Adekola, G. (2008). Fundamentals of Community Development in Nigeria, University of Port Harcourt Press, Port Harcourt. 